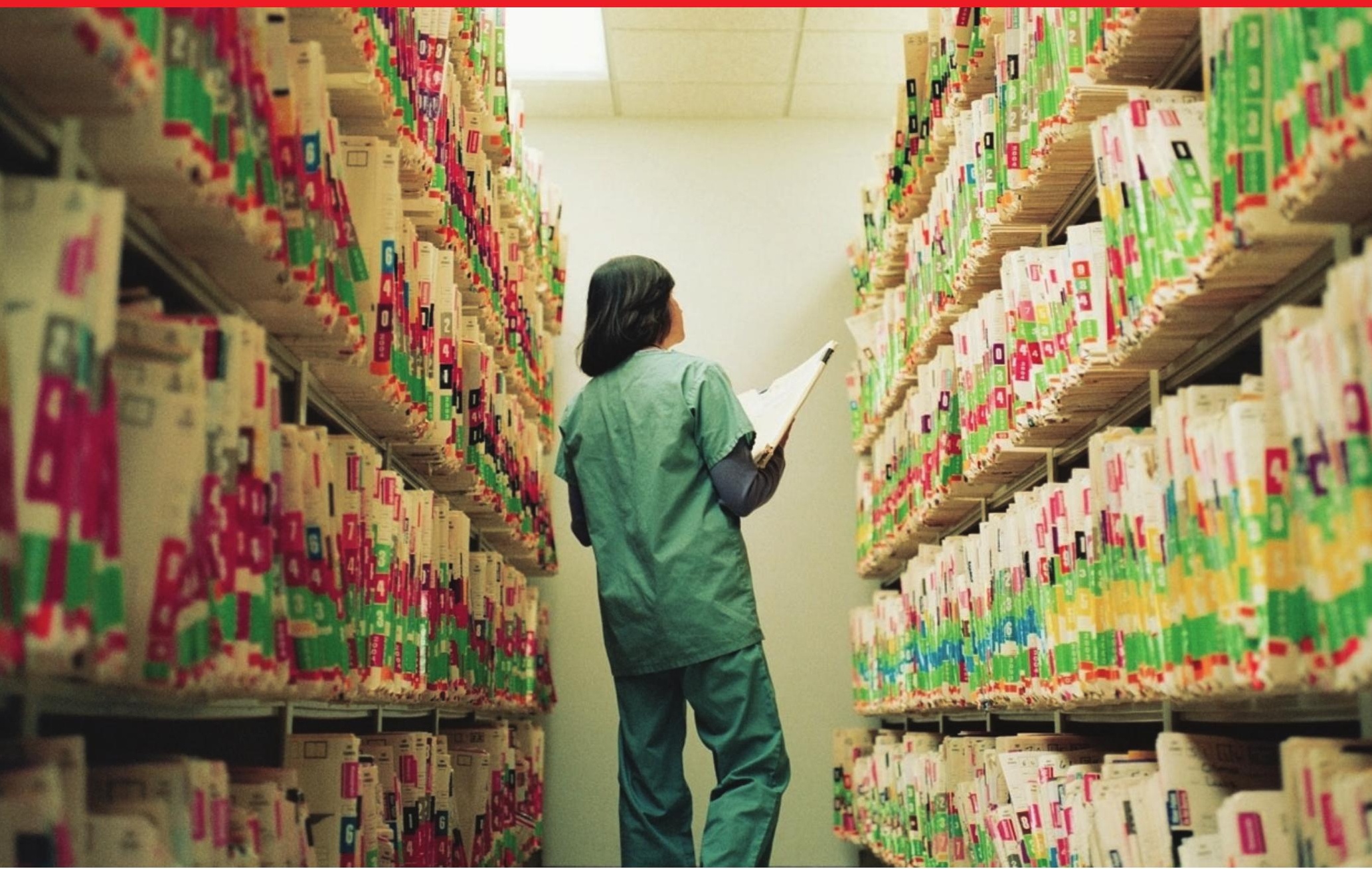

\title{
Archived answers
}

\section{カルテの電子化がもたらすもの}

Nature Vol.458(278-280)/19 March 2009

カルテの電子化を妨げているいくつかの大きな障害を乗り越えることができれば、研究へのデ一夕利用の可能性は大きく広がる だろう。Katharine Gammon の取材報告による。

1999 年 5 月、米国の食品医薬品局 （FDA）は 1 つの有望な新薬を承認した。 承認に先立って行われた 5000 名の患者 を対象とした臨床試験によって、関係者は、 この新薬が関節炎の痛みや炎症を安全に 低減させるのに有効だ、と確信したので ある。巨大製薬企業のメルク社が製造し たこの新薬は、瞬く間に大きく売り上げを 伸ばし、2004 年までに、世界中でおよそ 8000 万人がこの「特効薬」を服用した。

ところが、「Vioxx（バイオックス）」の
製品名（成分名はロフェコキシブ）で知ら れるこの鎮痛剤が広まるにつれ、心茞発 作のリスクが有意に高まる副作用を示す データが出てきた。FDA の研究者が中心 となった研究チームが 2005 年にLancet

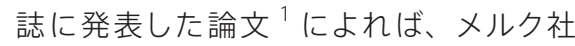
が 2004 年 9 月にこの鎮痛剂を市場から 回収するまで、「米国では重篤な冠状動脈 性心疾患が、おそらく8 万 8000 14 万件も増加したと見積もられる」という。 同研究チームは、バイオックスにより米国
だけで数万人の死者を出した可能性があ ると推定している。

しかし、紙媒体による記録から電子メ ディア記録へ移行する医療のデジタル革命 によって、今後は、バイオックスのように 死を招く事例の多くが防げることだろう。 2007 年、ボストン小児病院（米国、マ サチューセッツ州）の情報科学プログラム (CHIP) の研究チームは、電子カルテを 使うことでバイオックス問題をいかに迅速 に予見できるかを調べた ${ }^{2}$ 。研究チームが 
2 つの大きな病院に対象を絞って調べたと ころ、バイオックスが導入されて 8 か月以 内に心臓発作の件数が $18 \%$ も増加してい た。これがわかっていれば、バイオックス の危険性をいち早く察知することができた だろうと、論文著者の 1 人でCHIP の責 任者であるIsaac Kohane は話す。バイ オックスの回収により、このような心疾患 の増加はみられなくなった。

バイオックス事件は、医療制度におい て従来の紙媒体カルテから電子カルテへ 移行することで、プラスの効果が見込める ことを示している。英国などいくつかの国 では、既に電子カルテへ移行されており、 米国も現在、移行の方向に向かっている。 こうした動向は、医師が患者にどのような 治療をするか、また、研究者が医療デー 夕を使ってどのように基礎研究を行うかに も大きくかかわってくるだろう。

「長い目でみれば、さまざまなことが可 能になり、それによって全体にさらなる 変革が起こるかもしれません」と、ハー バード大学公衆衛生大学院(米国、ボ ストン) で保健政策の准教授を務める Ashish Jha はいう。「カルテの電子化に よって医療に関する情報交換が医師間で 自由に行われたら、いったいどれだけ巨 大なネットワークとなり、どれだけ膨大な 情報が飛び交うようになるのか、想像も つきません」。

ただし、その実現には時間がかかる。 カルテの電子化に向けた動きは、これま でのところゆっくりで、行く手には実務上 の課題が多数待ち受けている。J ha と彼 の同僚たちが 2007 年後期と 2008 年初 めに米国の医師を対象に調査したところ、 カルテシステムを完全に電子化していた のはわずか $4 \%$ 、簡易電子化システム を採用している医師も $13 \%$ しかいなかっ たのである ${ }^{3}$ 。「医療の機構や業務のあり 方は、ほぼ 100 年の間、変わっていない のです」とリhaは嘆く。

しかし、そうした状況も間もなく変わる ことになりそうだ。米国議会を最近通過し
た景気刺激策では、カルテの電子化を促 進するために 190 億ドル (約 1 兆 9000 億円； 1 ドル =100 円で換算、以下同様) の予算が組まれており、そのほとんどは医 師や医院による電子カルテ導入の奨励費 用に当てられている。そして最終的には、 2014 年までにすべてのカルテを電子化し て保存し、インターネットでアクセスできる ようにすることをめざしている。

バラク・オバマ米大統領は、右肩上が りの医療費を抑制する方法の 1 つとして、 この政策を押し進めている。もし医師の $90 \%$ が電子カルテシステムを使うように なれば、不要な治療の削減、治療のスピー ドアップ、医療過誤や手書きによる間違 いの低減によって、年間 810 億ドル（約 8 兆 1000 億円）が節約できると推定さ れる。投薬ミスや医療過誤が減少すれば、 人命も救われることになる。

\section{データの掘り起こし}

電子カルテに賛同する人々は、医療デー 夕の電子化によって研究者も大きな恩恵 を受けるだろうと考えている。医科学研究 で電子カルテを用いる根本的な理由の 1 つは、医師の大半が症状のパターンを認 識できるほど十分な数の患者をみていな いからである。カルテの数が数十万から 数百万件のレベルになってようやく、疾患 の関連性がみえてくるのである。また、患 者を募り、時間をかけて診断し検討する必 要がある場合には、研究にも時間がかかっ てしまうが、医療記録が電子化されてい れば、数回のクリックで関連データのすべ てを入手できるのである。

しかし、電子カルテに批判的な人々は、 現在の電子カルテはあまりにバラバラで 体系化されておらず信頼もできないとし、 医師の覚え書きをふるい分けるアルゴリズ ムさえもまだ使えないと主張している。

電子カルテの情報のあり方についても 疑問の声が上がっている。「研究したいこ とがあっても、それが一貫して必ず文書化 されているかどうかはわかりません」と、
カリフォルニア大学ロサンゼルス校（米 国）の医療グループおよび臨床系学部の メディカルディレクターである Samuel Skootsky はいう。

それに対しKohane は、電子カルテの 中にはデータの掘り起こしが十分に正当 化できるほど有用な情報が埋もれている と反論している。しかも、アクセスできる 患者デー夕は膨大な量であることから、研 究者は調べる患者を選別できるのだ。例 えば、喘息を調べようとする研究者は、他 の要因のせいで喘鳴のある患者と本当の 喘息患者とを区別することができるだろう と、Kohane は語っている。

彼によれば、研究を目的としている場 合、カルテの所見は臨床診察をより正確 に反映しているという。「もし、ある薬剤 を研究していて、対照集団に効果がある なら、それは非常に単純な研究です」と Kohane はいう。「しかし、その薬剤を服 用した人は誰でも、病状に関連する他の 薬剤もいくつか服用している可能性があ り」、それによって研究対象の薬剤の効果 が変わってしまうかもしれない。臨床試験 を行っている研究者がそうした情報を必ず しも入手できるとは限らないが、電子カル テシステムがあれば、こうした複数の薬 剤の効果を選り分けるのに役立つと考えら れる。

Kohane の研究チームは現在、こうし た可能性の検証として、カルテを利用して、 市販されている他の複数の薬剤について 調べている。彼らが探っているのは、薬剤 が市場に出る前の試験で見逃された可能 性のある副作用である。

また、電子カルテを遺伝学データベー スと組み合わせることで、さらに大き い威力を発揮できそうである。カリフォ ルニア大学ロサンゼルス校で医療科学 情報のディレクターを務める Michael Swiernikは、この組み合わせで、研究 の目的にあった人々をスピーディーに、な おかつ高い費用効率で見つけ出すことが できるだろうという。 
電子カルテから有用な医療データを掘 り起こせることは、他の研究でも確認され ている。2009年 2 月に、ある薬剤の有 効性を評価した場合に、電子カルテに記 録されたデータと、臨床試験のデータとが 同じ結果であったことが報告されたのであ る ${ }^{4}$ 。このデータは、一般開業医のカルテ のおよそ $10 \%$ が保存されている英国の一 般診療研究データベースから得られたも のである。このデータベースは主に人口 統計や薬剤利用に関連している。問題は、 英国のこの種のデータベースは小規模で 不完全であり、まだ互いに連結していな いことだ。

研究者が電子カルテに実際にアクセスで きるようになる前に、まず医療記録のデー タベースを作り上げてデータを充填しなけ ればならない。もし、2002 年にロサンゼ ルスのセダーズ・サイナイ医療センターで 起こったように、利用者たちが電子カルテ システムを拒絶した場合には、それまでと いうことになる。同センターでは、医師た ちが新しい電子カルテ連絡システムについ て数か月の研修を受けたが、あまりにわ ずらわしすぎると不満を訴えたのである。 ある日、職員たちは反乱を起こし、結局、 3400 万ドル（約 34 億円）もかけた電子 カルテシステムに移行しようという試みは、 わずか 3 か月で終焉を迎えてしまった。

職員の反乱に直面した医療機関は、セ ダーズ・サイナイ医療センターだけではな かった。米国内で電子カルテがこうした激 しい抵抗を招いている理由の 1 つは、こ れらのシステムから最も利益を得るのが 保険会社や組織の経理部門であって、こ の新ソフトウエアと研修の代価を払わされ る人々ではないからである。中規模の病 院の場合、こうした電子カルテシステムは ソフトウエアだけで数千万ドルかかり、投 資への見返りは保証されない。米国では 個人で開業かパートナー 1 名と開業してい る医師がほぼ半数なので、システム導入 の費用負担はばかにならず、試算によれ ば、システム導入で医師 1 人当たり 3 万

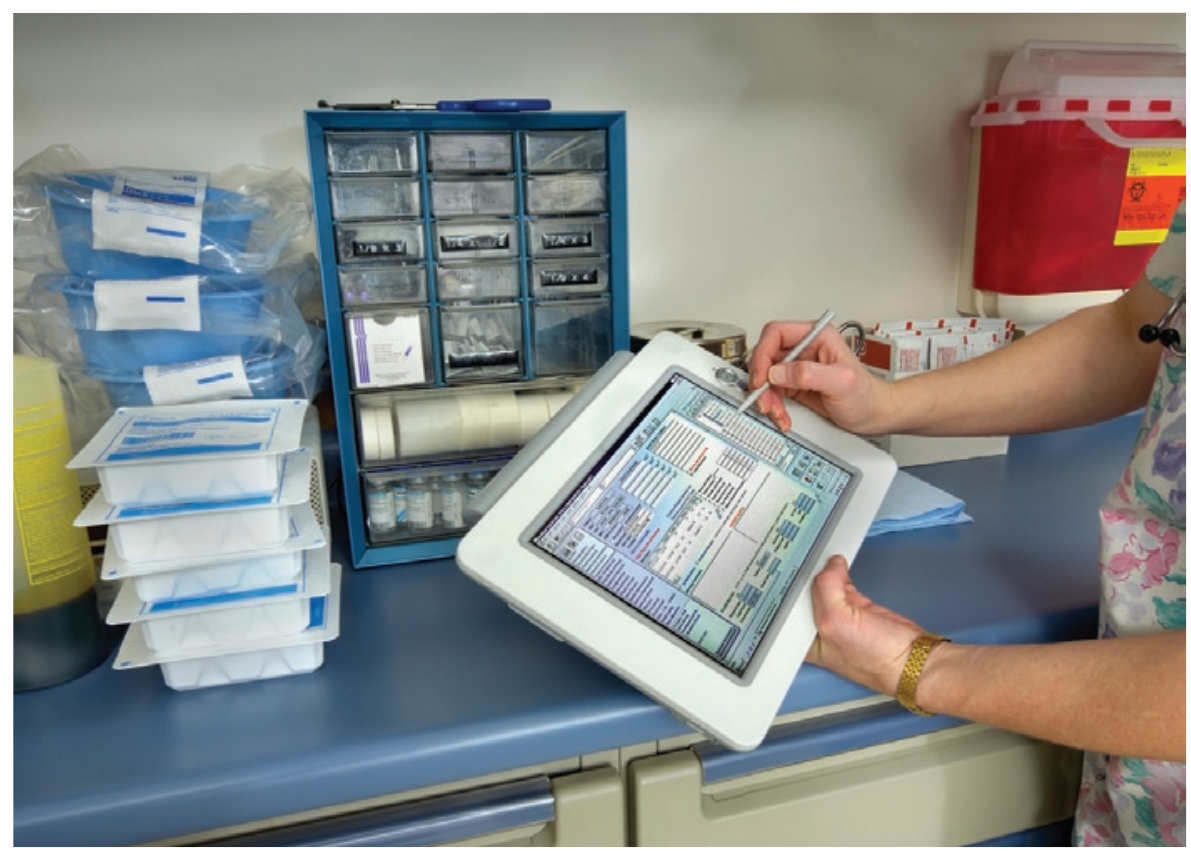

電子カルテは生命を救ったり経費を節約したりできるが、機密保護の面で懸念がある。

2000 ドル（約 320 万円）、システム稼 働のためにはひと月当たり 1500 ドル (約 15 万円）かかる。

医院もしくは医師が電子カルテシステム を購入しようとした場合、さらに別の難題 に直面することになる。何百もの業者がい て、それぞれ異なる独自の製品を売ろうと し、その多くは長く存続することがまずな いのである。しかも、電子カルテシステム では互いにデータを共有する必要があると いうことが、しばしば非オープンソース． システムでの問題点となる。これらの問題 のせいで、「医師や病院はこの技術の購 入に対して非常に神経質になっている」と Jha はいう。

また、システムの利用でも不安材料が ある。複数の研究から、電子カルテシス テムを利用し始めた最初の年には、医師 の作業能率が実際に $10 \sim 20 \%$ 低下する ことが明らかになっている。

次に、プライバシーという厄介な問題が 待ち受けている。患者に関する電子情報 が医師や製薬会社、研究室、経理部門の 間でやり取りされるということは、個人の 機密情報に多くの人がアクセスするという
ことである。それによって、機密保護が大 きく侵害されるリスクが生じる。事実、闇 市場ではカルテ情報がクレジットカード情 報よりも高值で売られている。その理由 は、カードよりも身元を特定しやすいため だと、Swiernikは話す。

「機密保護はシステムとして最低限保障 されるべきものであり、実際のところ、シ ステムに脆弱な部分が存在する可能性は 相当高いのです」とLee Tien はいう。彼 は、デジタル著作権を扱う公益グループ、 Electronic Frontier Foundation (米 国、カリフォルニア州サンフランシスコ) の弁護士で、とりわけデータの機密保護に ついて懸念を抱いている。その理由は、電 子カルテシステムへの移行が駆け足で起 こっているからである。「インフラの DNA ともいうべきプログラム心臓部に、個人情 報保護および機密保護をもともと組み込ん でおかなければ、残念ながらデータの機 密保護は完全には守られないでしょう」。

こうしたやっかいな問題があるにもかか わらず、なかには電子カルテシステムをう まく使いこなして恩恵を得ている医療機関 もある。医療サービスの提供と医療保険 
の支払いの両方を行う大規模な医療機関 は特にそうである。最大規模のシステム の代表的なものに、復員軍人援護局 (VA) のオープンソース・システムである VistA と、カイザー・パーマネンテ（米国最大 規模の非営利医療サービス組織; 米国、 カリフォルニア州オークランド） のシステ ムであるHealthConnect の 2つがある。 カイザー・パーマネンテの非営利医療保 険では、加入者 860 万人の医療記録が 完全に電子化されており、そのうちほぼ半 分はインターネットでオンラインアクセスで きるようになっており、加入者は自分の記 録の一部を見ることができる。

しかし、研究者たちはそうしたシステム から実質的な恩恵をいまだに受けていな い。カイザー・パーマネンテは、個人情 報保護の規定を理由に、保持している臨 床記録へのアクセスを主に同組織内の研 究者に限定している。VAもやはり、研究 に対しては腰が重い。「VAは10 年分の 電子データを蓄積していますが、臨床研 究に電子デー夕を利用できるのは、少数 の職員のみです」とJhaはいい、データ を匿名化して安全に共有する技術とそのレ ベルが、入手できるデータの量にまだ追 いついていないのだと説明する。
世界最大の電子医療記録システムは、 英国の国営保健サービス（NHS）で、 6000 万人以上が加入している。しかし、 英国の医師たちによって蓄えられたこの電 子データは、まだ完全には連結されてい ない。だが、今後 5 年で変わるはずである。 5 年後には電子医療記録システムによって 3 万人の一般開業医がつながれ、英国内 の全居住者に関するデータが保管される ことになる。

デジタル時代への移行を急ぐ一方で研 究の機会は見逃されてきたと、ウォーリッ ク大学 (英国、コヴェントリ) で疫学と公 衆衛生の准教授を務める John Powell はいう。「ちょうど今、患者の合意につい て大きな議論になっているところです。つ まり、研究システムに組み込まれること に患者が同意すべきかどうかという問題 です。大部分の医師は、患者はデー夕提 供に同意すべきだといっていますが、英 国保健省の担当者たちは同意すべきでな いと主張しています。研究の観点からす ると、我々は人数も内容も最大限のデー タが欲しいと思っています」。一方、一般 開業医は、たとえ患者の特定ができなく ても患者データの共有には慎重な姿勢を 示している。

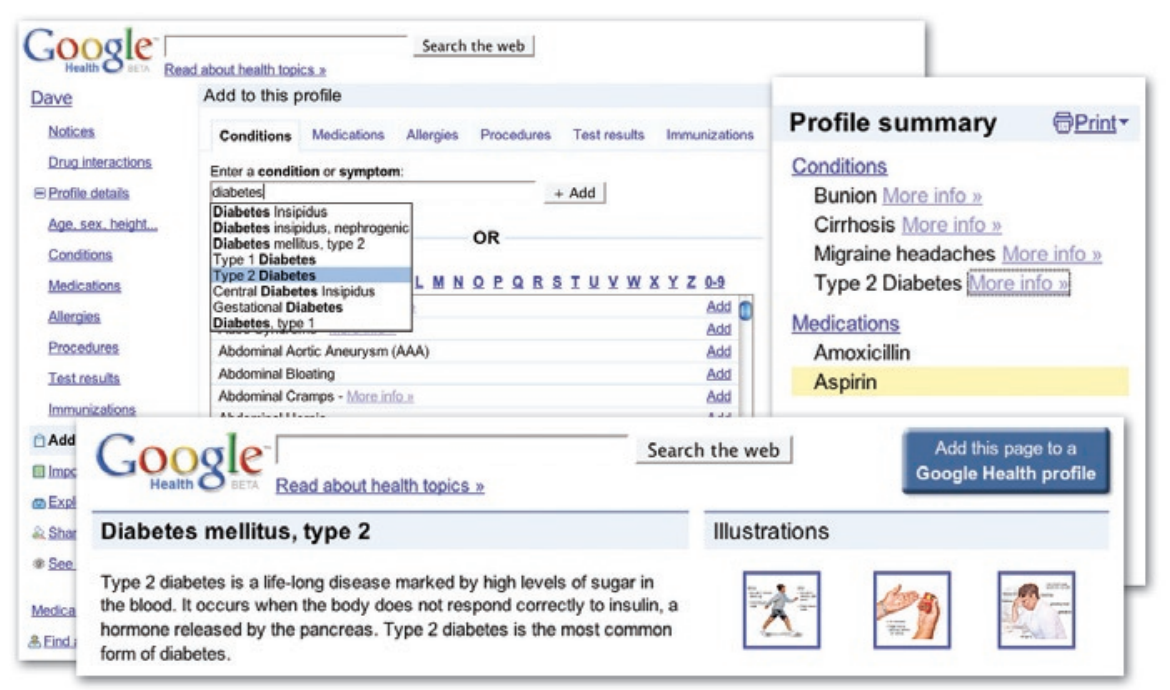

インターネットを使って、Google Health などの医療記録管理システムに自分の医療データを保存できる。
また最近、英国の一部当局者が、資金 調達のためにNHSが製薬会社へデータ を売る可能性があることを示唆し、システ ムへの懸念が高まった。この提言は、厳 しい批判を招いている。ただし Powell は、これらの問題の多くは年内に解決さ れ、その時点でNHS は、システムを利用 するためのサービス契約条件ともいえる公 的規約をまとめ上げることになるだろうと 話している。彼は、このシステムは研究 に使われるべきだという。「健康保険加入 者には、どんな医療でも完全に無料で受 けられるのと引き換えに、いくつかの項目 に同意の署名をしてもらいます。その中に は、NHS の匿名情報を用いた研究に関し て、データの二次利用の同意に関する項 目を入れるべきです。しかし、製薬会社に よる利用に関する項目は入れてはなりませ ん」とPowell はいう。

\section{機密保護に懸念}

英国はここ数年、デー夕機密保護にまつ わる大きな問題に何度か直面しており、 そのため当然のことながら、人々は自身 の医療情報の安全性について懸念を抱い ている。それでも、変化の予兆はある。 NHS 内の組織の 1 つである英国立衛生 研究所 (NIHR) が今年の 2 月に行った システム構築によって、システム内で匿名 化したデータをこれまでより容易にやり取 りできるようになるだろう。

ほかの欧州諸国では、自国の医療記録 をどのように取り扱うかがまだ決まってい ない。ドイツでは医師がその地域の電子 カルテを共有してはいるものの、それらを もっと大規模なシステムに連結する手だて はない。フランスは電子カルテを保管しア クセスもできる国立のシステムをもってい るが、臨床医は自分が関係する記録の一 部しか閲覧することができない。

一部の研究者は、Apple 社のiPhone のように、手軽に手ごろな值段で入手でき るアプリケーションをそろえている携帯端 末が、大規模で費用のかかるシステムに 
代わるものになるとみている。Kohane の話では、最良のシステムは、相互運用 可能かつ代用可能な異なるプログラムを 使って利用できるプラットフォームだろう という。

システム販売業者の問題のせいでオー プンソース・プラットフォームシステムが 構築されない場合、個人の健康管理記 録、つまり医療機関ではなく患者が自身で 管理・保存している電子記録の拡充のほ うが将来性があると、Kohane はみてい る。個人の健康管理記録のモデルは既に、 Google Health やマイクロソフト社の HealthVault や、CHIP の研究者たちに よって構築されたIndivo などのシステム にみられる。これらのシステムはいずれも、 医師のオフィスもしくは研究室から送信さ れた患者データを保管しており、データの 管理は患者個人に任されている。科学研 究に使用される場合、個人の記録であれ ば中間に病院や医師をはさまず患者と研 究者が直接結びつくことになり、多くの審 査機関が求めている匿名性も保てるだろう とKohane はいう。
こうしたシステムは、医学研究の大き な問題の 1 つを解決できるかもしれない。 現在、研究にデー夕を提供している人々 は匿名であり、研究結果は通常、そうし た人々に伝えられることはない。Kohane たちは、今年後半にボストンのあるクリ ニックで、患者 5000 人とのコミュニケー ションをより高める方法を検討する予定で あり、2010 年には参加するクリニックの 数をさらに増やすつもりである。この方法 では、患者はかかりつけの医療機関で登 録し、臨床もしくはゲノム上の情報を暗号 化された個人の医療記録システムヘアッ プロードし、それを研究者が共有する。そ の後、患者は自分の記録に関係する特定 の告示に「アクセス」することができる。

もし、得られた研究結果が患者のゲノ ムプロファイルと適合していれば、患者は その研究に関するメッセージを得られるだ ろう。また、がんや糖尿病といった特定 の疾患に関する情報を得るために登録す ることもできるだろう。また、研究者は患 者を特定することなくコミュニケーション をとることができ、継続的に交流すること
が可能になるだろう。「現在は、患者と研 究者が自主的にお互いを無視している状 態です」とKohane はいう。「患者は自 分が関係している研究について詳細を求 めない旨を誓約させられますし、研究者 は患者についてさらなる情報を得ること はできないのです」。

医療システムがこれらの大きいハードル を乗り越えたなら、すべてが変わるだろう。 情報が瞬時に手に入り、米国大統領でさえ もブラックベリーを親指で操作するような 世の中なのだから、電子カルテシステムも あっという間に実現するだろうし、それとと もに研究の好機も到来するだろう。多くの 研究者にとって、時代のこうした移り変わ りはまさに願ってもないものである。

Katharine Gammon は、米国カリフォルニア州サン タモ二カを活動拠点とするフリーランス・ライターである。

1. Graham, D. J. et al. Lancet 365, 475-481 (2005).

2. Brownstein, J.S., Sordo, M., Kohane, I. S. \&Mandl, K. D. PLoS ONE 2, e840 (2007).

3. DesRoches, C. M. et al. N. Engl. J. Med. 359, 50-60 (2008)

4. Tannen, R. L., Weiner, M. G. \& Xie, D. Br. Med. J. 338, b81 (2009).

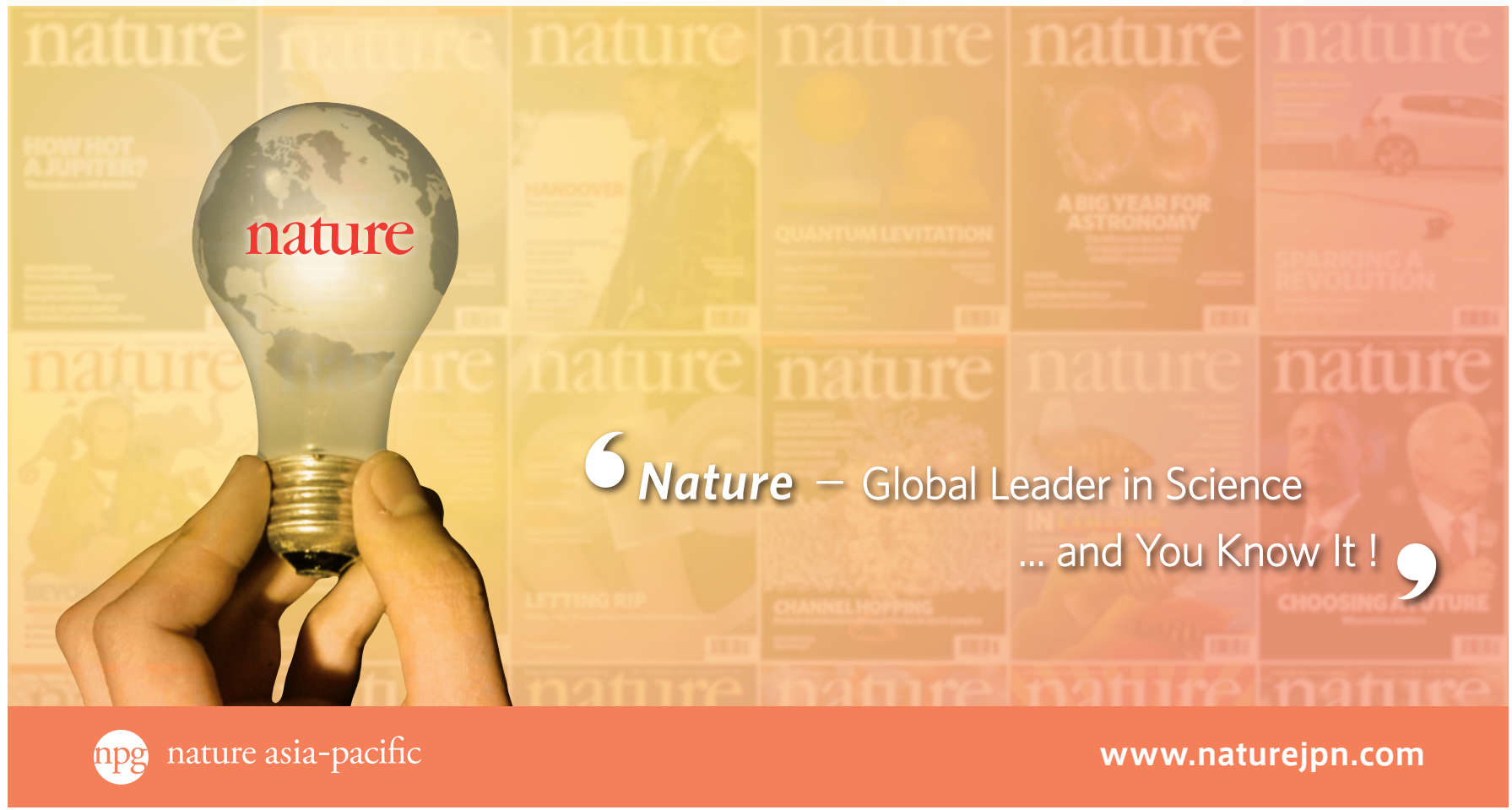

